\title{
THE IMPACT OF RELATIONSHIP MARKETING ON CUSTOMER LOYALTY IN THE TOUR AND TRAVEL COMPANIES IN MALAYSIA DURING COV-19 PANDEMIC: PARALLEL MEDIATION OF SOCIAL MEDIA AND RELATIONSHIP QUALITY
}

\author{
Kumaran Kanapathipillai ${ }^{i}$, \\ Nur Nadiah Mahbob \\ Faculty of Business and Technology, \\ UNITAR International University, \\ Tierra Crest, Jalan SS6/3, \\ Kelana Jaya, 47301 Petaling Jaya, \\ Selangor, Malaysia
}

\begin{abstract}
:
The aim of this research was to examine the parallel mediating effect of social media and relationship quality between relationship marketing and customer loyalty. A series of regression analysis provided the statistical result that tested the hypothesis proposed in this research. The total population of the travel and tourism firms registered with the Ministry of Tourism, Arts and Culture was 4746. The results of this study were obtained from data collected through 361 out of 600 self-administered questionnaires. A series of regression analysis assessed the impact of relationship marketing on customer loyalty in the tour and tourism companies in Malaysia. The results indicated that social media platforms utilised and the application of relationship quality are statistically significant and mediates the relationship between relationship marketing and customer loyalty. It can be concluded accurately from the literature and the statistical analysis conducted that there is concrete evidence that relationship marketing impacts customer loyalty. The intervening variables tested were social media use and relationship quality. The outcomes verified that social media and relationship quality are crucial factors that induces customer loyalty. Both social media and relationship quality defines how the effects between relationship marketing and customer loyalty occur. The mediating effects of social media and relationship quality between relationship marketing and customer loyalty are the actual factors that generate customer loyalty which then leads to customer retention and repeat purchase in the travel and tourism sector in Malaysia.
\end{abstract}

Keywords: relationship marketing, customer loyalty, social media, relationship quality, parallel mediation

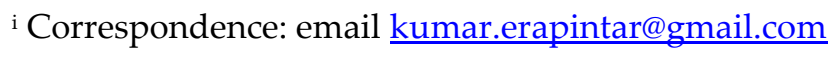




\section{Introduction}

The third-largest contributor to the Malaysian Gross Domestic Product is the Tourism industry (MOTAC, 2021). Regarding the performance of tourism in Malaysia, only an insignificant increase of $1.0 \%$ or (26.1 million) was recorded in international tourist arrivals in the year 2019 compared to 2018 at (25.8 million). However, in terms of tourist expenditure, there was an increase of 2.4 per cent from RM84.1 billion in 2018 to RM86.1 billion in 2019 (MOTAC, 2021).

In early 2019, the region of Southeast Asia has experienced significant growth in the travel and tourism industry. Therefore, Malaysia was also eager to capitalise on this development and launched the "Visit Truly Asia Malaysia 2020" campaign. As a result, Malaysia anticipated a staggering 30 million visitors and revenue of RM100 billion in travel and tourism receipts in 2020.

However, the well thought out tourism campaign had to be cancelled due to the spread of the silent killer (COVID-19) pandemic, which ravaged the country and put the travel and tourism industry at a standstill. However, in certain regions of Malaysia, the unrestricted movements intensified knowledge of new tourism locations, and the increased use of social media as a medium of communication and trade heightened the travel and tourism industry.

On the other hand, public concern has increased about the industry's effect on the environment. This has led to consumer demand for more viable travel preferences. As such, the travel and tourism industry's environmental impact significantly deteriorated when the Covid-19 pandemic started its rampage throughout the whole country. As a result, travel bans and physical detachments were enforced, causing an overwhelmingly negative impact on Malaysia's travel and tourism industry, just as the rest of the world. When it comes to the future of the travel and tourism industry, relationship marketing through increased utilisation of social media and relationship quality may be the solution for the industry to recover its momentum when the travel restriction is uplifted.

\subsection{Overview of Past, Present and Future Tourism Development in Malaysia}

Tourism and leisure have been a favoured activity in Malaysia even before Malaysia's independence in 1957. The government's participation in tourism development began in 1953 during the era of British colonialization in Malaysia. Since then, the tourism industry, just as other industries, has flourished tremendously until the onslaught of the Covid-19 pandemic in late 2019.

Malaysia has been a favourite destination for many tourists worldwide, and it is the second most visited destination after Thailand (Sakolnakorn, 2020). Table 1.1 illustrates the tourism development plan in Malaysia from 1991 to 2030, which is a portion of the national economic plan. 
Table 1.1 Tourism development of Malaysia between 1991 and 2030

\begin{tabular}{|c|c|}
\hline Year & Policy and Implementation \\
\hline $\begin{array}{c}\text { Sixth National } \\
\text { Development Plan } \\
(1991-1995)\end{array}$ & $\begin{array}{l}\text { - Government promoted and supported Malaysian tourism } \\
\text { - Government concern to raise employment rate with tourism activities } \\
\text { - Government focusses on promoting business, service, and activities } \\
\text { related to tourism } \\
\text { - Government set up policy to promote tourism connections to other } \\
\text { industries, such as handicraft, cultural places, small enterprises, or } \\
\text { industrial sector for making products for overseas tourists }\end{array}$ \\
\hline $\begin{array}{c}\text { Seventh National } \\
\text { Development Plan } \\
(1996-2000)\end{array}$ & $\begin{array}{l}\text { Development activities and products for responsiveness to tourism } \\
\text { needs } \\
\text { - Promote activities related to tourism such sport, water tourism, } \\
\text { shopping, and meeting activities } \\
\text { - Promote business related to tourism } \\
\text { - Encourage local business and residents to have more participation and } \\
\text { - Infrastructure development }\end{array}$ \\
\hline $\begin{array}{c}\text { Eighth National } \\
\text { Development Plan } \\
(2001-2005)\end{array}$ & $\begin{array}{l}\text { - Tourism management by balancing tourism activities and social, } \\
\text { economic, environmental, cultural, and traditional issues } \\
\text { - Promote cultural heritage and physical environment tourism } \\
\text { - Present and promote tourism in Malaysia } \\
\text { - Develop security and safety (reducing crime) and tourism facilities }\end{array}$ \\
\hline $\begin{array}{c}\text { Ninth National } \\
\text { Development Plan } \\
(2006-2010)\end{array}$ & $\begin{array}{l}\text { - Focus on tourism sustainability } \\
\text { - } \quad \text { Encourage service sector using technology and innovation for tourism } \\
\text { Tourism development based on market demand and continuous } \\
\text { tourism promotion on media } \\
\text { Develop new tourism activities and promote Malaysia as a second } \\
\text { home of world's residents }\end{array}$ \\
\hline $\begin{array}{l}\text { Tenth National } \\
\text { Development } \\
(2011-2015)\end{array}$ & $\begin{array}{l}\text { - Central government encouraged state governments to develop tourism } \\
\text { based on their core competencies } \\
\text { - Encourage cultural tourism, eco-tourism, homestay, sport activities, } \\
\text { island and coast tourism, meetings, incentive travel, conventions, } \\
\text { exhibitions, food and beverage, shopping, and medical activities (set up } \\
\text { medical hub to motivate overseas patients } \\
\text { to come to treatment in hospitals) } \\
\text { - Improved tourism image } \\
\text { - Set up “Green and Clean Malaysia" policy and safety for tourists. } \\
\text { - Infrastructure investment, especially public transportation and } \\
\text { renovated airport } \\
\text { Promote tourism in Malaysia, emphasis on European countries } \\
\text { Human development to raise worker skill to support tourism business and } \\
\text { quality of service }\end{array}$ \\
\hline
\end{tabular}




\begin{tabular}{|c|c|}
\hline $\begin{array}{c}\text { Eleventh } \\
\text { National } \\
\text { Development } \\
(2016-2020)\end{array}$ & $\begin{array}{l}\text { - Revised tax policy (e.g., tax exemption of luxury goods, duty free shops), } \\
\text { encouraged private sector to open new department stores and shopping } \\
\text { plazas } \\
\text { - } \text { Development of big cities such as Kuala Lumpur as shopping centres } \\
\text { - Encourage spa and health massage tourism } \\
\text { - Promote and more infrastructure development in Sabah and Sarawak } \\
\text { - More infrastructure and city development in undeveloped areas such as } \\
\text { - } \text { Eelantan state to promote new tourism destinations } \\
\text { - More infrastructure development with overseas companies, such as } \\
\text { railways, airports, roads, electrical vehicles, and bus stations (also } \\
\text { - Mproved buses) } \\
\text { - Continuously promote green and clean Malaysia }\end{array}$ \\
\hline $\begin{array}{c}\text { National } \\
\text { Tourism Policy } \\
(2020-2030)\end{array}$ & $\begin{array}{l}\text { - Transforming the governance policy of tourism related agencies in } \\
\text { Malaysia to harness their tourism core skills } \\
\text { - Create special tourism investment zones to drive the development of } \\
\text { high value and innovative tourism products and services in response to } \\
\text { growing market sophistication } \\
\text { - Embarking on a competitive digitalization ourney to transform } \\
\text { Malaysia's tourism industry towards Smart Tourism } \\
\text { - Nurturing demand sophistication bu increasing the depth of the tourist } \\
\text { experience in support of sustomised and discerning travel } \\
\text { Aligning the National Tourism Policy towards the United Nations } \\
\text { Sustainable Development Goals by reinforcing the role of tourism as a } \\
\text { catalyst for economic development in a sustainable responsible and } \\
\text { inclusive manner } \\
\text { Nurturing the development of a service culture through capacity } \\
\text { building and human capital development that cascades seamlessly from } \\
\text { the macro level to the destination level }\end{array}$ \\
\hline
\end{tabular}

Source: Adapted from Prime Minister's Office of Malaysia Website and The Ministry of Tourism, Arts, and Culture.

\subsection{Research Problem}

Threatened by intense competition within the tourism industry and the onslaught of the silent killer, Covid-19 pandemic, travel and tourism companies have been implementing various marketing strategies to sustain in an economic environment that has come to a standstill (Kanapathipillai, 2020; Abbruzzese et al., 2020). Tourism consumers are also being troubled by various marketing initiatives undertaken by travel and tourism agencies who have resorted to customer loyalty programs, the internet and online social media (Bilgin, 2018; Godey et al., 2016) to promote their tour packages. There are also indications that consumers are switching (Keaveney, 1995) to competitors' travel and tour agencies when they cannot be satiated by the relationship quality (Ma et al., 2020; Ruswanti and Lestari (2016); Bojei and Alwie (2010); Basalamah et al., 2018; Marina, 2016; Parasuraman, 1985) provided by some of the travel and tourism companies.

Numerous travel and tourism companies have contemplated relationship marketing as an ultimate strategy to retain customers and develop customer loyalty 
(Basalamah et al., 2018; Holley, 2011; Sheth \& Parvatiyar, 2000). Furthermore, several previous research has provided substantiations that relationship marketing strategies (Khoa, 2019; Aldaihani \& Azman, 2019; Abdolaziz \& Mostafa, 2016; Husnain \& Akhtar, 2015; Nauroozi \& Moghadam, 2015; Menteiro \& Afonso, 2010) have a significant positive impact on creating customer loyalty. Consequently, the challenges faced by the travel and tourism companies during the Covid-19 pandemic is creating awareness of their services. As such, the travel and tourism companies could use online social media (Bilgin, 2018) and provide optimum relationship quality (Samudro et al., 2019; Bajs et al., 2015; Abdullah et al., 2013; Basalamah et al., 2018; Njuguna \& Mirugi, 2017; Marina, 2016, Parasuraman, 1985). This way, the travel and tourism companies may have an excellent chance to build an excellent relationship with consumers and ultimately create customer loyalty (Ma et al., 2020; Ruswanti and Lestari (2016); Shaimaa \& Doma, 2013; Sirdeshmukh et al., 2002).

\subsection{Research Objectives}

RO1: To examine the significant relationship between relationship marketing and customer loyalty in the travel and tourism companies in Malaysia.

RO2: To scrutinize the significant relationship between relationship marketing and social media in the travel and tourism companies in Malaysia.

RO3: To investigate the significant relationship between social media and customer loyalty in the travel and tourism companies in Malaysia.

RO4: To analyse the significant relationship between relationship marketing and relationship quality in the travel and tourism companies in Malaysia.

RO5: To explore the significant relationship between relationship quality and customer loyalty in the travel and tourism companies in Malaysia.

RO6: To study the mediating effect of social media between relationship marketing and customer loyalty in the travel and tourism companies in Malaysia.

RO7: To investigate the mediating effect of relationship quality between relationship marketing and customer loyalty in the travel and tourism companies in Malaysia.

\subsection{Research Questions}

RQ1: Is there a significant relationship between relationship marketing and customer loyalty in the travel and tourism companies in Malaysia?

RQ2: Is there a significant relationship between relationship marketing and social media in the travel and tourism companies in Malaysia?

RQ3: Is there a significant relationship between social media and customer loyalty in the travel and tourism companies in Malaysia?

RQ4: Is there a significant relationship between relationship marketing and relationship quality in the travel and tourism companies in Malaysia?

RQ5: Is there a significant relationship between relationship quality and customer loyalty in the travel and tourism companies in Malaysia? 
RQ6: How does social media mediates the relationship between relationship marketing and customer loyalty in the travel and tourism companies in Malaysia?

RQ7: How does relationship quality mediates the relationship between relationship marketing and customer loyalty in the travel and tourism companies in Malaysia?

\section{Literature Review}

The following section provides a theoretical background with regards to the association between relationship marketing, social media, relationship quality and customer loyalty.

\subsection{Relationship Marketing and Customer Loyalty}

The primary purpose of all businesses is to create excellent brand equity by formulating relationships with their customers, stimulating heightened purchase intention, retention and loyalty towards the products or services. To continuously exceed customer expectations and ensure unceasing customer loyalty, marketers must constantly find new ways to build relationships with existing and prospects. Building relationships is even more crucial now to retain and create loyal customers as the whole world is experiencing an economic meltdown due to the outbreak of the SARS-CoV-2, commonly known as Covid-19, which has ravaged many nations worldwide.

Through relationship marketing, businesses create trust in customers, which induces customer loyalty. As elucidated by (Shalabaya, 2012; Too et al., 2001; Cottrell, 1995), relationship marketing stimulates trust in the form of product or relationship quality (Al-Hawary, 2013), business commitment and competent employees will enable businesses to attain loyalty of their customers and gain competitive advantage in the marketplace. Additionally, (Ndubisi, 2007; Ndubisi \& Chan, 2005) claimed that customer loyalty could be increased through appropriate relationship marketing plans which focuses on initiating trust (Al-Hadid et al., 2014), presenting dedicated services (Abu alNaja, 2008), having continuous communication to answer consumer doubts and queries. This can be supported by (Al-Hawary \& Aldaihani, 2016; Abtin \& Pouramiri, 2016; Bolton et al., 2000; De Wulf et al., 2001; Verhoef, 2003), who mentions that businesses attain victory when customer loyalty is crafted through strategic relationship marketing which will generate lasting and steady affiliation with customers that enables the business to obtain feedback from customers in term of their expectations and loyalty towards the product or services. Furthermore, recent research (Aldaihani \& Azman, 2019) found that the relationship marketing components such as interaction, collaboration, proficiency, obligation, and trust in customers' loyalty are statistically significant.

Therefore, from the literature provided, it can be concluded that there is a significant correlation between relationship marketing and customer loyalty. Relationship marketing is a crucial component for all businesses, which helps create trust, commitment, and dedication that eventually leads to better customer loyalty. Based on this theoretical literature, the following hypothesis is formulated: 
H1: There is a statistically significant relationship between relationship marketing and customer loyalty in the travel and tourism companies in Malaysia.

\subsection{Relationship Marketing and Social Media}

The current economic turmoil caused by the SARS-CoV-2 pandemic faced by many businesses, including the tourism industry, has compelled marketers to use social media in creating relationships (Kanapathipillai, 2021). Therefore, incorporating social media strategy into relationship marketing has become the next frontier for all businesses to improve communication and build a more robust and stable relationship with customers. The advent of social media has allowed customers to share their opinions and experiences with marketers and build mutually beneficial relationships (Jiaqi et al., 2021; Kotler et al., 2010). Furthermore, based on (Albeza et al., 2013; Constantinides \& Fountain, 2008; Mangold \& Faulds, 2009), online social media shapes an atmosphere where customers can develop stable and rapid relationships in which both marketers and consumers can enthuse each other's ideas, feelings and understanding of the products or services.

Kotler et al. (2010) further explain that relationship marketing formed via contemporary social media platforms have significantly influenced the marketplace power grids, bringing about a substantial shift in market power to consumers. Subsequently, (Jiaqi et al., 2021; Kaplan \& Haenlein, 2016; Hennig-Thurau et al., 2010) mention that the social media phenomenon has given marketers an upper hand to ensure that the relationship marketing strategy implemented yields more significant returns. In support of this, (Miller \& Lammas, 2010) has found that online social media inspires businesses to maintain direct communication with customers without any intermediaries to build superior marketing relationships.

Previously, marketers were having difficulty formulating a promising relationship marketing strategy that would yield optimum trust, commitment and satisfaction that leads to superior customer loyalty. Traditionally, marketers were heard saying that relationship marketing devised by their company was just an inactive one-way relationship and communication (Beech et al., 2000). Nevertheless, online social media has provided more excellent opportunities for businesses to engage with customers far and near, which has dynamically improved relationship marketing efforts (Drury, 2008). Additionally, when technologically advanced, portable and more powerful mobile devices were introduced, relationship marketing through online social media was made possible for marketers to contact more prospective customers (Suseno et al., 2018; Leidner and Kayworth, 2016; Hennig-Thurau et al., 2010). Based on these studies, the hypothesis is formulated as follows:

H2: There is a statistically significant relationship between relationship marketing and social media in the travel and tourism companies in Malaysia.

\subsection{Social Media and Customer Loyalty}

In the current unfavourable milieu, acquiring customer loyalty is crucial for all businesses and the travel and tourism sector. According to (Werthner \& Klein, 1999), the tourism 
sector is an information-focused industry that leads e-commerce growth. Therefore, social media plays a crucial role as an information resource for travelling consumers (Gretzel, 2018; Ladkin \& Buhalis, 2016; Madera, 2012; Fotis et al., 2011; Gretzel et al., 2011; Kietzmann et al., 2011; Xiang \& Gretzel, 2010).

Based on (Kanapathipillai, 2021; Munar et al., 2013), social media is a contemporary type of sociality that induces customer loyalty and ensures long-term relationships. Furthermore, (Leung et al., 2013; White \& White, 2007; Foux, 2006) mention that when travel and tourism agencies utilise online social media, customers can stay connected with the agency and their loved ones during their travel increases loyalty towards the company. Additionally, (Chathoth et al., 2016; Dijkmans et al., 2015) elucidate that the consequence of effective and constant contact with travellers by tourism companies significantly increases the company's reputation and stimulates travellers loyalty behaviour. Therefore, tourism companies cannot take online social media for granted as it is a vital tool that cocreates long-term relationships and customer loyalty among travellers (Gretzel \& Dinhopl, 2014).

Through the use of social media, customers can experience their product and service choices and continuously communicate with sellers, which increases brand loyalty (Hutter et al., 2018). According to (Ahmed \& Saeed, 2020; Vollmer \& Precourt, 2008; Rashtchy et al., 2007), online social media platforms are the supreme selection to reach and stimulate current and probable consumers much faster and efficiently, which will then create customer loyalty. Furthermore, with the government's emphasis on physical distancing due to the ravaging Covid-19 virus, online social media technology is the new hymn encompassing innovation to solve customers' dilemmas and enhance customer loyalty (SI, 2016).

Research reveals that social media can also affect the customer's decision-making process (Baird and Parasnis, 2011; Kaplan \& Haenlein, 2010; Mangold \& Faulds, 2009; Constantinides et al., 2008). Customers can make better brand choices through social media's online features, improving their buying experience and leading to repeat purchases because of the loyalty induced (Bhagat et al., 2009). Additionally, marketers are investing tremendously in social media platforms not to miss out on any prospective customers who could one day become loyal to the product or service offering (Baines \& Fill 2014; Mangold \& Faulds, 2009).

Analysis shows that online buyers are growing by the numbers, and marketers utilise online social platforms to build customer loyalty (Dubois \& Westerhausen, 2011). Various methods are used to create customer loyalty through online social media, including brand connection, group engagement, and impression management (Laroche et al., 2012; Dubois \& Westerhausen, 2011).

The above literature undoubtedly implies that social media induces customer loyalty. Therefore, it can conclude that when online social media is woven into the fabric of the travel and tourism sector, it will become a formidable sector with loyal travellers, which in turn helps the travel agencies to grow and sustain in a crisis environment. Based on these findings, the hypothesis is formulated as follows: 
H3: There is a statistically significant relationship between social media and customer loyalty in the travel and tourism companies in Malaysia.

\subsection{Relationship Marketing and Relationship Quality}

Many organisations, large and small, have invested in relationship marketing to gain customers' attention, repurchase and loyalty (Stringer, 2006). Relationship marketing benefits both customers and the business (Kahn, 1990; Salanova et al., 2005). According to (DeWitt \& Brady, 2003), relationship marketing escalates repurchase intention and reduces negative perceptions of a product or service.

Relationship marketing becomes stronger and everlasting between an organisation and its customer when relationship quality in terms of customer satisfaction and confidence and organisational commitment exists (Jin, Choi, \& Goh, 2011; Palmatier et al., 2006).

Additionally, (Tseng, 2007; Naude \& Buttle, 2000) mentions that relationship quality depends on a service provider who is highly committed and can confidently serve the customers. This is parallel to the findings of (Shahrokh et al., 2013; Henning-Thurau et al., 2002; Palmatier et al., 2006) that relationship quality enhances the relationship between the customer and the business as a result of customer satisfaction, trust and past experiences.

Furthermore, many scholars have discovered that the greater the relationship quality forged between the customer and the business, the more effective relationship marketing (Ogungbade, 2015; Crosby et al., 1990; Smith, 1998). Based on (Ma et al., 2020; Ogungbade, 2015), relationship marketing is the grassroots of relationship quality. According to (Smith, 1998; Grosby et al., 1990), relationship quality is vital for the valuation of the potency of relationship marketing via customer gratification and faith in the service provided by the business. In addition, both marketers and customers regard relationship quality as a vital factor in maintaining a continuous relationship, eventually leading to greater loyalty (Bowen \& Shoemaker, 2003).

Consequently, (Rezaei \& Khajei, 2011), in their research, have found that relationship permanency can be measured by relationship quality between an organisation and its customers. High relationship quality results from the organisations' integrity when servicing customers and when the customer develops confidence in the services rendered by the organisation (Rezaei \& Khajei, 2011). In the words of (Gummesson, 1994,1998), relationship quality is an added value provided by a business when relationship marketing is selected as a strategy to gain customers' attention and loyalty.

Thus, the above literature indisputably infers that relationship quality is vital for the permanency of relationship marketing. Maintaining high relationship quality ensures higher relationships are forged between the seller and buyer, which results in the survival of the travel and tourism agencies during adverse environmental conditions. According to these studies, the hypothesis is formulated as follows: 
H4: There is a statistically significant relationship between relationship marketing and relationship quality in the travel and tourism companies in Malaysia.

\subsection{Relationship Quality and Customer Loyalty}

Based on (Oliver, 1999) customer loyalty is a profoundly held obligation to repurchase a favoured brand regularly, regardless of environmental or personal impacts, and relationship quality as a marketing effort can be a probable cause for consumers to switch brands.

Researches have been carried out regarding relationship quality in the travel and tourism industry (Hu et al., 2009; Kim and Han, 2008; Beatson et al., 2007; Sanchez et al., 2007; Moliner et al., 2007; Liang and Wang, 2006). Some of the studies have indicated that relationship quality has a significant positive impact on customer loyalty (Ma et al., 2020; Ruswanti \& Lestari, 2016; Bojei \& Alwie, 2010); Hennig-Thurau et al., 2002; Liang and Wang, 2006; Lin and Ding, 2009; Ben Naoui and Zaiem, 2010). Furthermore, research undertaken by (Mimouni \& Volle, 2003; Wong \& Sohal, 2006) further confirmed that relationship quality positively impacts customer loyalty. Additionally, the study by (Huang, 2012) has proven that relationship quality creates customer loyalty by high customer satisfaction. Furthermore, research conducted on a freight forwarding company by (Shaimaa \& Doma, 2013) has confirmed that relationship quality has a significant and positive effect on customer loyalty. Another study conducted in a distribution setting by (Vesel \& Zabkar, 2010) has also exhibited that relationship quality stimulates customer loyalty.

Therefore, it can be established that customers who perceive a high level of relationship quality will exhibit loyalty behaviour towards a company and will be willing to patronise a company's products or services continuously. Therefore, as inferred in the literature above, the following hypothesis is formulated as follows:

H5: There is a statistically significant relationship between relationship quality and customer loyalty in the travel and tourism companies in Malaysia.

\subsection{Relationship Marketing and Customer Loyalty is mediated by Social Media}

Social media plays a crucial role between relationship marketing and customer loyalty. This theoretical perspective presented in this section provides superior knowledge on how customers involvement in social media affects relationship marketing variables to induce loyalty. In addition, several previous research conducted provides an understanding of the mediating role of social media and social media marketing between relationship marketing and its outcomes such as customer loyalty and purchase intentions.

Nowadays, most businesses have opted to rely on online social media to create customer loyalty or e-loyalty (Gamboa \& Goncalves, 2014). According to (Kim et al., 2009; Reichheld et al., 2000), the only difference between conventional customer loyalty creation and contemporary customer loyalty creation is the cost to establish an online platform which is pricey. However, the returns from contemporary loyalty creation 
through online social media is much greater and swifter. Additionally, (Gamboa \& Goncalves, 2014) have discovered that when businesses indulge in relationship marketing with customers utilising online social media, an emotional link is shaped, leading to stable customer loyalty.

According to (Mershon, 2012) social media furnishes customers with a formidable and effective voice in their interactions with marketers. Social media offers purchasers a say that marketers cannot disregard. Additionally (Mershon, 2012) also mentions that eighty-five per cent of organisations found that social media was the best medium to create a relationship with clients and stimulate customer loyalty.

Based on (Brodie et al., 2011; Gummerus et al., 2012), social media allows interactive content creation, which enables the formation of a good relationship with customers, stimulating enhanced customer loyalty. Furthermore, (Vivek et al., 2012) investigated the nature and scope of relationship marketing, in which the involvement and contribution of prospective customers via social media triggered greater customer loyalty. Additionally, (Habibi and Richard, 2014; Turri et al., 2013) proposed that using social allows marketers to participate with their clients by offering content that creates attention and interest in customers, leading to greater loyalty to the product or service.

From the findings of (Pongpaew et al., 2016; Balakrishnan et al., 2014; Bilgihan et al., 2013; Fuentes-Blasco et al., 2010), it was noted that the influence of social media towards customers' loyalty is significant and implied that online social media helps form a formidable relationship with customers which then leads to greater customer loyalty. The above outcomes undoubtedly imply that social media mediates the relationship between relationship marketing and customer loyalty. Therefore, maintaining a social media platform is significant for the travel and tourism operators in this study. According to these studies, the hypothesis is formulated as follows:

H6: Social media mediates the relationship between relationship marketing and customer loyalty in the travel and tourism companies in Malaysia.

\subsection{Relationship Marketing and Customer Loyalty is Mediated by Relationship Quality}

Travel and Tourism companies operating in a highly turbulent environment which is also plagued by the Covid-19 pandemic, are increasingly dependent on the relationship with their customers. These service-oriented companies, such as the travel and tourism operators, must constantly interact with their prospects through relationship marketing. However, relationship marketing alone will not be able to induce customer loyalty. Relationship quality as an intervening factor needs to be significantly considered to induce a positive consequence of relationship marketing. Therefore, relationship quality can be described as a significant construct associated with customers' evaluation of their overall relationship with the travel and tourism agencies at a specific time grounded on all previous dealings with the agencies (Crosby et al., 1990). 
Customer loyalty results from effective relationship marketing and relationship quality or service quality rendered by a firm (Chen \& Myagmarsuren, 2013; Keshavarz \& Ali, 2015). Furthermore, (Mola \& Jusoh, 2011) contended that the non-existence of relationship quality is the main cause of customer disloyalty and dissatisfaction towards a product or service.

Previous researchers (Lin \& Ding, 2006; Oliver, 1999; Morgan \& Hunt, 1994; Bejou et al., 1996) discovered an association between relationship quality and the loyalty of customers. Additionally, according to the findings of (Ndubisi, 2007), relationship quality built through relationship marketing enables businesses to attain valuable marketing intelligence, which enhances customer loyalty. More recently, based on the study conducted by (Ma, Jang \& Lai, 2020; Ruswanti \& Lestari, 2016; Keshavarz et al., 2016; Zhang et al., 2011; Keating et al., 2010) have found that relationship quality mediated the association between relationship marketing and customers' loyalty.

According to (Tseng, 2007), research conducted in several service sectors (tourism, airline and banking) has proven that relationship quality creates long-term relationships between the firms and customers and prompts customer loyalty. This evidence can be further supported by the findings of (Samudro et al., 2019; Bajs et al., 2015; Abdullah et al., 2013; Nakhleh, 2012; Moliner, 2007; Rauyruen \& Miller, 2007; Han, 2008), which confirmed that relationship quality mediated the association between relationship marketing and customer loyalty. Therefore, it can be generalised that relationship quality reflects the nature and intensity of any relationship between customers and businesses. This is parallel to (Smith, 1998), who mentioned that relationship quality demonstrates the positive consequence that reveals the force of relationship marketing to produce customer loyalty. According to these studies, the hypothesis is formulated as follows:

H7: Relationship quality mediates the relationship between relationship marketing and customer loyalty in the travel and tourism companies in Malaysia.

\subsection{Proposed Parallel Mediating Conceptual Model}

From the literature search, it was ascertained that relationship marketing affects customer loyalty. Both social media and relationship quality mediates the relationship between relationship marketing and customer loyalty. Moreover, based on the literature presented, this research was designed to examine how relationship marketing (independent variable) significantly influences customer loyalty (dependent variables) of employees through social media and relationship quality (parallel mediating variables). Subsequently, based on the literature assessed, Figure 1 conceptual framework illustrates the hypothesised relationships. 


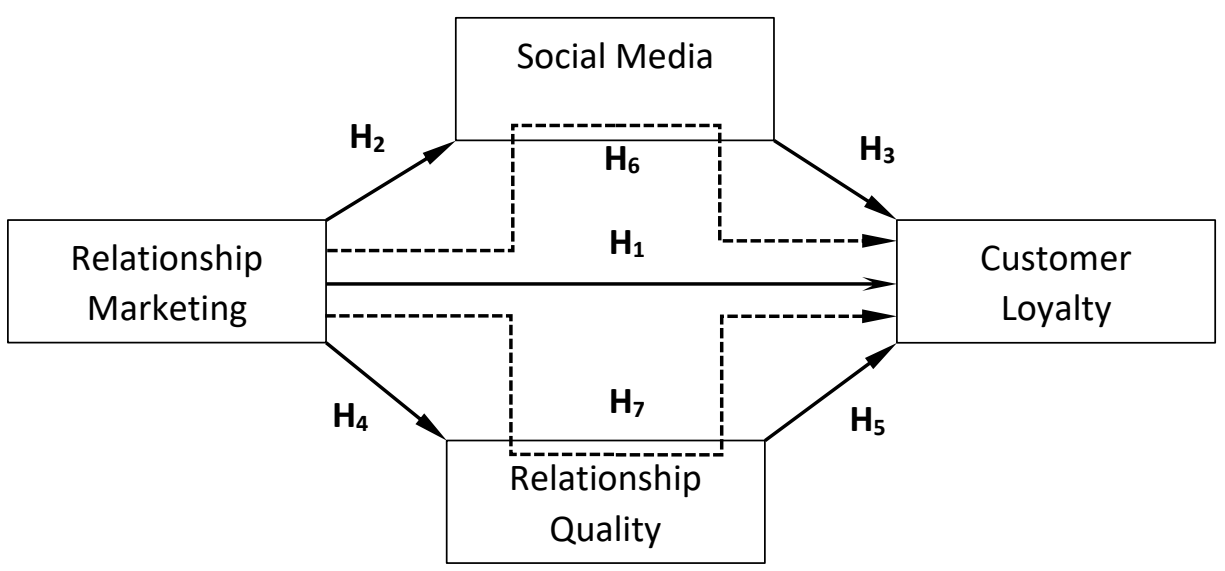

Figure 1: Conceptual Framework

\section{Methodology}

This study examines the relationship between relationship marketing and customer loyalty with social media and relationship quality as parallel mediating factors. A total of 420 self-administered survey questionnaires were distributed to the travel and tourism agencies in Malaysia. The questionnaires utilised Likert's 5-points scale varying from "Strongly disagree (1)" to "Strongly agree (5)". The survey instrument is comprised of five parts. The first part aimed to obtain data about the demographic profile of the respondents. The second part provided data on the relationship marketing factor (independent variable), the third part furnished data on social media used (intervening variable). The fourth part generated data on relationship quality (intervening variable). Finally, the fifth part contributed data on customer loyalty (dependent variable).

For this study, the 5-point Likert's scale was applied. To measure the relationship marketing factor, the questions were formed based on (Aldaihani \& Azman, 2019; Shalabaya, 2012). It measured 6 items. Next, to attain data on social media use, the questions were based on (Kanapathipillai, 2021; Gretzel, 2018; Hutter et al., 2018). The measure contained 5 items. To analyse the relationship quality factor, questions were created according to (Ma, Jang \& Lai, 2020; Al-Hawary, 2013). The measure comprised of 6 items. To study the customer loyalty factor, questions were constructed grounded on (Aldaihani \& Azman, 2019; Chen \& Myagmarsuren, 2013; Keshavarz \& Ali, 2015). The measure contained 5 items. The demographic profile contained 4 questions to identify the respondent's profile.

The reliability of the instrument used to gather data was tested. The Cronbach's Alpha values were all $0.7<\alpha<0.9$, which showed the internal consistency of the questionnaire is good. Table 3.1 summarises the reliability of the instrument used in this study. 


\begin{tabular}{lcc}
\hline & Table 3.1: Reliability Analysis & \\
\hline Variables & Cronbach's Alpha & No of Items \\
\hline Relationship Marketing & 0.811 & 6 \\
Social Media & 0.768 & 5 \\
Relationship Quality & 0.748 & 6 \\
Customer Loyalty & 0.864 & 5 \\
\hline
\end{tabular}

\subsection{Population, Sampling and Measurement}

The population of this study are the small and medium travel and tourism operators who are registered with the Ministry of Tourism, Arts and Culture Malaysian (MOTAC). Based on (MOTAC, 2021) database, as of April 2021, there were 4746 travel and tour operators in Malaysia. To obtain an appropriate sample size for this research from the population, the (Krejcie and Morgan, 1970) population and sample size tabulation was used. Based on (Krejcie and Morgan, 1970) tabulation, the alpha value is 0.05, and the degree of accuracy is 0.05 . Thus, no calculations were required when establishing the sample size for this research. As the number of travel and tourism operators in Malaysia is 4746 (MOSTAC, 2021), according to (Krejcie and Morgan, 1970) tabularisation, the sample size is approximately 357. Therefore, a sample size of 400 employees is regarded as a fit for this study by the researcher.

A simple random sampling technique was used in this study. The respondents voluntarily partook in the survey without any coercion. Additionally, the necessary approvals were obtained from the management of the travel and tourism companies to gather the data from the managers and owners. A total of 600 questionnaires were sent via google platform and e-mail to the travel and tourism companies in Malaysia based on the database provided by MOTAC. A total of 368 questionnaires were received, which is approximately a $61.3 \%$ return rate. While codification, it was disclosed that 7 out of 368 questionnaires that were returned were only partially completed. Therefore, the data from 361 fully completed questionnaires were input into SPSS Version 26. Correlation analysis was used to determine the association between variables. Hayes Process Macro Version 3.5 (Model Number:4) was used to test the parallel mediation effect (Hayes \& Rockwood, 2020; Hayes, 2013).

\section{Findings and Interpretations}

This section presents the outcomes of this study to give a comprehension of the demographics factors, association between variables and the relationships between the independent, parallel mediation and dependent variables.

\subsection{Demographic Profile of Respondents}

The profile of the employees studied is presented in Table 2. 


\begin{tabular}{|l|l|c|c|}
\hline \multicolumn{4}{c}{ Table 4.1: Employees' Profile (N=361) } \\
\hline \multirow{2}{*}{ Demographics } & Category & Frequency & Percentage \\
\hline \multirow{3}{*}{ Gender } & Male & 243 & 67.3 \\
\cline { 2 - 4 } & Female & 118 & 32.7 \\
\hline \multirow{4}{*}{ Age } & Manager & 268 & 74.2 \\
\hline \multirow{5}{*}{ Academic Qualification } & Owner & 93 & 25.8 \\
\hline & $21-30$ & 78 & 21.6 \\
\cline { 2 - 4 } & $31-40$ & 122 & 33.8 \\
\cline { 2 - 4 } & $41-50$ & 104 & 28.8 \\
\cline { 2 - 4 } & $51-60$ & 57 & 15.8 \\
\cline { 2 - 4 } & SPM/STPM (Secondary) & 176 & 48.8 \\
\cline { 2 - 4 } & Undergraduate & 141 & 39.1 \\
\cline { 2 - 4 } & Postgraduate & 44 & 12.1 \\
\hline
\end{tabular}

Based on Table 4.1 demographics survey of the travel and tourism companies show that the majority of the respondents are males (67.3\%). A majority of $(74.2 \%)$ of the respondents are managers. In terms of age, the majority are $31-40$ years old (33.8\%). Finally, in terms of academic qualification the majority of the employees are secondary school graduates $(48.8 \%)$.

\subsection{Mean, Standard Deviation and Normality Analysis}

Table 4.2: Descriptive Statistics

\begin{tabular}{lcccccc}
\hline Factors & Mean & SD & Skew & Kurtosis & Min & Max \\
\hline Relationship Marketing & 2.656 & 0.781 & 0.714 & 0.189 & 1.5 & 5.0 \\
Social Media & 2.701 & 0.765 & -0.011 & -0.226 & 1.0 & 4.4 \\
Relationship Quality & 2.613 & 0.829 & 0.442 & 0.314 & 1.0 & 5.0 \\
Customer Loyalty & 2.817 & 0.757 & 0.084 & -0.869 & 1.4 & 4.4 \\
\hline
\end{tabular}

The descriptive statistics in Table 4.2 displays the mean, standard deviation (SD), skewness and kurtosis values of this study. From Table 4.2, customer loyalty shows the highest mean value of $2.817 \pm 0.757$. The lowest mean value is relationship quality, 2.613 \pm 0.829 . The normality test shows that the skewness and kurtosis values have a threshold of \pm 1 which means that the data are distributed normal as clarified by (Chinna \& Yuen, 2015; Gravetter \& Wallnau, 2014).

\subsection{Correlation Analysis}

Table 4.3: Pearson's Correlation Matrix (N=361)

\begin{tabular}{lcccc}
\hline Variables & RM & SM & RQ & CL \\
\hline Relationship Marketing (RM) & 1 & & & \\
Social Media (SM) & $0.859^{* *}$ & 1 & & \\
Relationship Quality (RQ) & $0.941^{* *}$ & $0.918^{* *}$ & 1 & \\
Customer Loyalty (CL) & $0.858^{* *}$ & $0.961^{* *}$ & $0.888^{* *}$ & 1 \\
\hline$* *$ Cortation
\end{tabular}

** Correlation is significant at the 0.01 level (2-tailed) 
To study how the variables are correlated, the correlation matrix with $(\mathrm{N}=361)$ is presented in Table 4.3. Based on the correlation matrix obtained, it was observed that data adequately supported the measurement model. First, Pearson's correlation of relationship marketing and customer loyalty was highly positive and statistically significant $(r=0.858 ; p<0.001$. Hence, there is a positive association between relationship marketing and customer loyalty. Secondly, Pearson's correlation on relationship marketing and social media was also highly positive and statistically significant $(r=0.859$; $\mathrm{p}<0.001)$. Therefore, there is a positive association between relationship marketing and social media. Thirdly, the Pearson's correlation of social media and customer loyalty was discovered to be also very highly positive and statistically significant $(r=0.961 ; p<0.001)$. Consequently, there is a positive association between social media and customer loyalty. Fourthly, Pearson's correlation of relationship marketing and relationship quality was observed to be also very highly positive and statistically significant $(\mathrm{r}=0.941 ; \mathrm{p}<0.001)$. As a result, there is a positive association between relationship marketing and relationship quality. Finally, the Pearson's correlation of relationship quality and customer loyalty was disclosed to be highly positive and statistically significant $(r=0.888$; $\mathrm{p}<0.001$. Thus, there is a positive association between relationship quality and customer loyalty.

\subsection{Series of Regression Analysis}

A series of regression analysis were carried out to test the hypothesis in this study to scrutinise the direct and indirect (mediation) effects. The mediation analysis is conducted using Hayes Process: Model number 4 (Hayes \& Rockwood, 2020). Figure 2: Parallel Mediation Model shows the direct ( $\left.a, b, c, d, e^{\prime}\right)$ and indirect (f, g) path effects between the variables in this study.

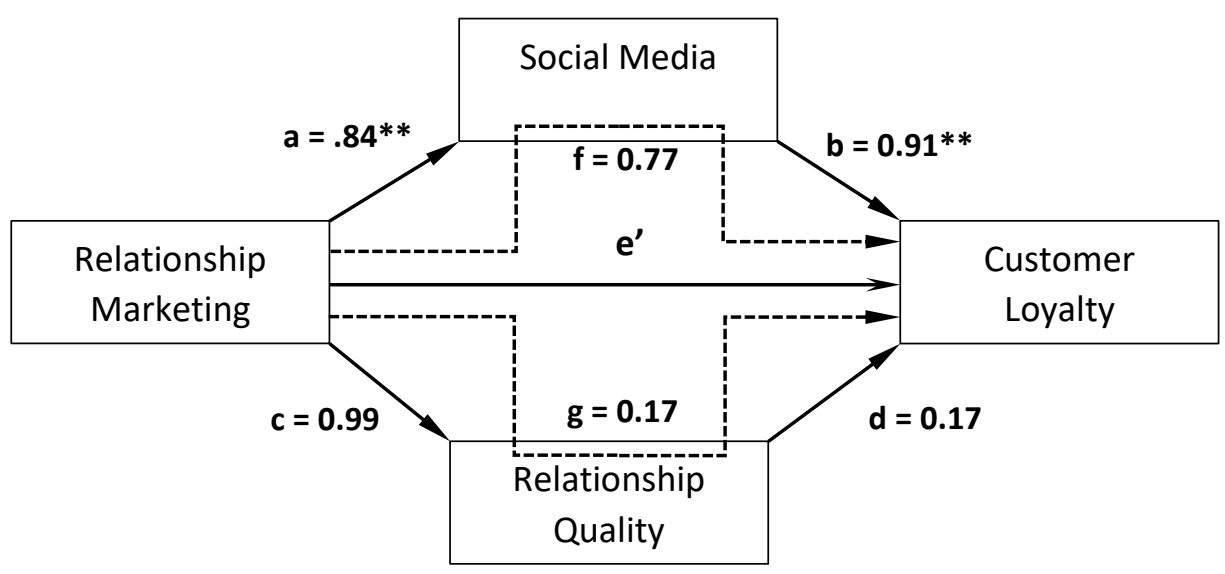

Figure 2: Parallel Mediation Model 


\begin{tabular}{|c|c|c|c|}
\hline \multicolumn{4}{|l|}{ Table 4.4: Path Coefficient } \\
\hline Path & B & SE & $\mathrm{p}$ \\
\hline (a) Relationship Marketing ---------------> Social Media & 0.8419 & 0.0265 & $<0.001$ \\
\hline --_--_------> Customer Loyalty & 0.9190 & 0.0352 & $<0.001$ \\
\hline (c) Relationship Marketing ----------------> Relationship Quality & 0.9986 & 0.0190 & $<0.001$ \\
\hline (d) Relationship Quality ----------------> Customer Loyalty & 0.1654 & 0.0489 & $<0.001$ \\
\hline (e') Relationship Marketing -----------------> Customer Loyalty & 0.2225 & 0.0403 & $<0.001$ \\
\hline (Indirect: f) Relationship Marketing--->Social Media--->Customer Loyalty & 0.7737 & 0.0322 & $<0.001$ \\
\hline $\begin{array}{l}\text { (Indirect: g) Relationship Marketing-->Relationship Quality-->Customer } \\
\text { Loyalty }\end{array}$ & 0.1652 & 0.0375 & $<0.001$ \\
\hline (Total Effect) Relationship Marketing $=========\Rightarrow$ Customer Loyalty & 0.8310 & 0.0263 & $<0.001$ \\
\hline
\end{tabular}

Table 4.5: Indirect Effect(s) of $X$ on $Y$

\begin{tabular}{lcccc}
\hline Effect ( X on Y) & Effect & BootSE & BootLLCI & BootULCI \\
\hline Total & 0.6085 & 0.0352 & 0.5414 & 0.6772 \\
Social Media & 0.7737 & 0.0322 & 0.7143 & 0.8402 \\
Relationship Quality & 0.1652 & 0.0375 & 0.0945 & 0.2420 \\
\hline
\end{tabular}

\subsubsection{Direct Effects}

Table 4.4: Path Coefficient shows that the series of regression sub-models. The first regression sub-model shows the direct path (a) between relationship marketing and social media is statistically significant $(B=0.8419 ; \mathrm{p}<0.001)$, which reveals that relationship marketing turned out as a positive and statistically significant predictor of social media. According to this finding, there is a significant relationship between relationship marketing and social media in Malaysia's travel and tourism companies. Thus, the Hypothesis $\mathrm{H} 2$ is supported by data.

The second regression sub-model shows that the direct path (b) between social media and customer loyalty is statistically significant $(B=0.9190 ; p<0.001)$, which discloses that social media is a positive and statistically significant predictor of customer loyalty. According to this finding, there is a significant relationship between social media and customer loyalty in Malaysia's travel and tourism companies. Therefore, hypothesis H3 is supported by data.

The third regression sub-model shows that the direct path (c) between relationship marketing and relationship quality is statistically significant $(B=0.9986 ; p<0.001)$, which uncovers that relationship marketing is a positive and statistically significant predictor of relationship quality. Based on the outcome, there is a significant relationship between relationship marketing and relationship quality in Malaysia's travel and tourism companies. Therefore, hypothesis $\mathrm{H} 4$ is supported by data.

The fourth regression sub-model shows that the direct path (d) between relationship quality and customer loyalty is statistically significant $(B=0.1654 ; p<0.001)$, which unveils that relationship quality turned out as a positive and statistically significant predictor of customer loyalty. Based on the outcome, there is a significant relationship between relationship quality and customer loyalty in Malaysia's travel and tourism companies. Therefore, hypothesis $\mathrm{H} 5$ is supported by data. 
The fifth regression sub-model shows that the direct path (e') between relationship marketing and customer loyalty is statistically significant $(B=0.2225 ; p<0.001)$, which exposes that relationship marketing turned out as a positive and statistically significant predictor of customer loyalty. Based on the outcome, there is a significant relationship between relationship marketing and customer loyalty in Malaysia's travel and tourism companies. Therefore, hypothesis $\mathrm{H} 1$ is supported by data.

\subsubsection{Indirect Effects (Mediation Outcome)}

According to Table 4.5 Indirect Effect(s) of $X$ on $Y$, it was found that the unstandardised coefficient of total indirect effect $(B=0.6085$; BootSE=0.0352). According to Table 4.4 Path Coefficient, the total effects $(B=0.8310 ; S E=0.0263)$. Therefore, the total indirect effect is less than the total effects. It is, therefore, a partial mediation. Additionally, based on Table 4.5 Indirect Effect(s) of $X$ on $Y$, the zero value does not fall between the BootLLCI and BootULCI. Thus, the mediation is statistically significant. Based on Table 4.4, analysing the indirect effect path (f), the outcome reveals that social media partially and significantly mediates the relationship between relationship marketing and customer loyalty $(\mathrm{B}=0.7737 ; \mathrm{p}<0.001)$. Thus, hypothesis H6 is supported by data.

Finally, examining the indirect effect path $(\mathrm{g})$, the outcome reveals that relationship quality partially and significantly mediates the relationship between relationship marketing and customer loyalty $(B=0.1652 ; p<0.001)$. Therefore, hypothesis H7 is supported by data.

\section{Discussion}

This study focused on the parallel mediating effects of social media and relationship quality between relationship marketing and customer loyalty in Malaysia's travel and tourism sector. A total of 361 responses from the managers and owners of the travel and tourism companies were collected to generate the outcome.

The first objective of this study was to examine the significant relationship between relationship marketing and customer loyalty in the travel and tourism companies in Malaysia. As a result, hypothesis $\mathrm{H} 1$ is supported by data and unveiled a statistically significant relationship between relationship marketing and customer loyalty. This outcome is parallel to the findings of (Al-Hawary \& Aldaihani,2016; Abtin \& Pouramiri, 2016; Ndubisi, 2007; Ndubisi \& Chan, 2005), who found that customer loyalty can be enhanced through appropriate relationship marketing plans which will lead to a lasting connection with customers that enables the business to retain customer and encourage repeat purchase.

The second objective of this study was to scrutinise the significant relationship between relationship marketing and social media used in the travel and tourism companies in Malaysia. Hypothesis $\mathrm{H} 2$ is supported by data and revealed a statistically significant relationship between relationship marketing and social media. This result can be supported by previous studies conducted by (Jiaqi et al., 2021; Kotler et al., 2010; 
Albeza et al., 2013), who identified that social media provides an opportunity for customers to furnish fruitful feedback to the travel and tourism firms, which the firm could use to improve its relationship with the customers.

The third objective of this research was to investigate the significant relationship between social media and customer loyalty. Hypothesis H3 is supported by data and exposed a statistically significant relationship between social media and customer loyalty. The results obtained from this research can be supported by (Kanapathipillai, 2021; Gretzel, 2018), who mention that social media is vital for travellers and a source of information that encourages long-term relationships and customer retention.

The fourth objective of this study was to analyse the significant relationship between relationship marketing and relationship quality. Hypothesis $\mathrm{H} 4$ is supported by data and exposed a statistically significant relationship between relationship marketing and relationship quality. Furthermore, the outcome of this study can be reinforced through previous research conducted by (Ma et al., 2020; Ogungbade, 2015), who highlighted that as relationship quality rises, the relationship between the customer and the firm increases, which eventually leads to greater trust in the part of the customer towards the travel agency.

The fifth objective of this study was to explore the significant relationship between relationship quality and customer loyalty. Hypothesis H5 is supported by data and disclosed a statistically significant relationship between relationship quality and customer loyalty. This discovery can be supported by (Ma et al., 2020; Ruswanti \& Lestari, 2016 who confirmed that relationship quality positively impacts customer loyalty.

The sixth objective of this research was to study the mediating effect of social media between relationship marketing and customer loyalty. Hypothesis H6 is supported by data and disclosed that social media mediates the relationship between relationship marketing and customer loyalty. Several previous researchers (Pongpaew et al., 2016; Gamboa \& Goncalves, 2014; Gummerus et al., 2012; Mershon, 2012) corroborate this finding through their study showed that when social media is used, relationship marketing can heighten customer loyalty.

The seventh objective of this study was to investigate the mediating effect of relationship quality between relationship marketing and customer loyalty. Hypothesis H7 is supported by data and disclosed that relationship quality mediates the relationship between relationship marketing and customer loyalty. This outcome can be reinforced by research conducted by previous scholars (Ma, Jang \& Lai, 2020; Samudro et al., 2019; Ruswanti \& Lestari, 2016; Keshavarz et al., 2016), who established that relationship quality built through relationship marketing facilitates businesses to acquire valuable information which augments customer loyalty.

\section{Conclusion and Managerial Implications}

This research was performed to determine if a parallel mediation existed between relationship marketing and customer loyalty. The intervening variables tested were 
social media use and relationship quality. The outcomes verified that social media and relationship quality are crucial factors that induce customer loyalty. Both social media and relationship quality defines how the effects between relationship marketing and customer loyalty occur. The mediating effects of social media and relationship quality between relationship marketing and customer loyalty are the actual factors that generate customer loyalty, leading to customer retention and repeat purchase in the travel and tourism sector. This can be validated by the discoveries of earlier scholars (Samudro et al., 2019; Pongpaew et al., 2016; Keshavarz \& Ali, 2015; Bajs et al., 2015; Balakrishnan et al., 2014; Gamboa \& Goncalves, 2014; Chen \& Myagmarsuren, 2013; Abdullah et al., 2013; Bilgihan et al., 2013; Fuentes-Blasco et al., 2010; Mershon, 2012).

This study also determined that initiating relationship marketing in travel and tourism firms will induce trust in customers, which stimulates customer loyalty. This was corroborated by (Aldaihani \& Azman, 2019; Al-Hawary \& Aldaihani,2016; Abtin \& Pouramiri, 2016; Shalabaya, 2012; Too et al., 2001; De Wulf et al., 2001; Ndubisi, 2007; Bolton et al., 2000; Verhoef, 2003; Cottrell, 1995) who mention that businesses attain victory when customer loyalty is crafted through strategic relationship marketing. This will establish a permanent and sound affiliation with customers that empowers businesses to respond to their expectations.

The managerial implication is to create a long-lasting relationship with the customer so that loyal customer who would continue to purchase the offerings by the travel and tourism firms. In order to ensure the everlasting customer relationship is maintained, managers and owners of the travel and tourism firms have to invest further or improve their social media platforms. As emphasised by (Kanapathipillai, 2021; Gretzel, 2018; Hutter et al., 2018; Ladkin \& Buhalis, 2016), customers can experience their product through social media and service choices as well as continuously communicate with the sellers, which enhances loyalty.

Additionally, managers and owners of the travel and tourism firms should ensure consistent high quality in their services. The managers and owners must work with the Ministry of Tourism, Arts and Culture (MOTAC) to provide the ultimate quality services to the local and foreign tourists. By accentuating the best relationship quality, the travel and tourism firms would withstand the after-effects of the economic downturn caused by the Covid-19 pandemic. As elucidate by Ma et al., 2020; Ruswanti \& Lestari, 2016), businesses that enforce excellent relationship quality procedures would be able to create everlasting customer loyalty.

Finally, the outcome of this research can be a benchmark that will irradiate that the utilisation of social media technology and emphasis on relationship quality will ensure the continued survival of all travel and tourism agencies in Malaysia. More specifically, the result of this research would help owners, managers and scholars as to why social media technology and relationship quality are vital when businesses engage in relationship marketing. 


\section{Limitations and Future Research}

The focus of this study was only on the small and medium-sized travel and tourism firms in Malaysia. However, to gain complete knowledge and understanding of these parallel mediating factors, further research can be undertaken on the larger tourism companies established in Malaysia

\section{Acknowledgements}

The authors would like to express gratitude to all the managers and owners of the travel and tour agencies involved in this research for allowing the authors to undertake this research and appreciate the time they have spent responding to the questionnaire.

\section{Conflict of Interest}

As far as the authors are concerned, there are no conflicts of interest connected with this research, and there has been no sponsorship of any nature that could have influenced its outcomes. As the researcher of this study, the authors confirm its novelty and have not been published previously and affirm that it is not presently being considered for publication elsewhere.

\section{About the Authors}

The authors are attached to UNITAR International University, a renowned private university in Malaysia, as scholars and researchers in the Faculty of Business and Technology. They have been involved in academic and research activities for the past two decades.

\section{References}

Abbruzzese, J., Ingram, D., \& Click, S. (2020). The Coronavirus Pandemic Drove Life Online. It May Never Return: What Passes for Normal Life Now Happens Almost Entirely. NBC News, 28th March, 2020, Retrieved from https://www.nbcnews.com/tech/internet/coronavirus-pandemic.

Abdolaziz, A., \& Mostafa, P. (2016). The Impact of Relationship Marketing on Customer Loyalty Enhancement (Case study: Kerman Iran insurance company). Marketing and Branding Research, 3, 41-49.

Abdullah, M. F., Putit, L., \& Chui, C. B. (2013). Impact Of Relationship Marketing Tactics (RMT's) \& Relationship Quality on Customer Loyalty: A Study Within the Malaysian Mobile Telecommunication Industry. Social and Behavioral Sciences 130, $371-378$

Abeza, G. \& O'Reilly, N. \& Reid, I. (2013). Relationship Marketing and Social Media In Sport. International Journal of Sport Communication, 6(2), 120-142. 
Abtin, Abdolaziz \& Pouramiri, Mostafa (2016). The impact of relationship marketing on customer loyalty enhancement (Case study: Kerman Iran insurance company). Marketing and Branding Research, 3, 41-49.

Abu al-Naja, M. A. A. (2008). Marketing Management: Contemporary Approach. Alexandria, Egypt: University House.

Ahmed, T., \& Saeed, A. (2020). The Impact of Social Media Marketing on Urban Youth's Brand Loyalty: Through Facebook Marketing. International Journal of Entrepreneurial Research, 4(1), 10-19.

Al-Hadid, A., Shoutar, A., \& Batayneh, K. (2014). Factors Affecting Customer Loyalty in Jordanian Banking Sector, A Field Study. Journal of Administrative Sciences Studies, 41 (2), 312-325.

Al-Hawary, S. I. S. (2013). The Roles of Perceived Quality, Trust, and Satisfaction in Predicting Brand Loyalty: The Empirical Research on Automobile Brands in Jordan Market. International Journal of Business Excellence (IJBEX). 6(6), 656-686.

Al-Hawary, S. I. S. \& Aldaihani, F. M. (2016). Customer Relationship Management and Innovation Capabilities of Kuwait Airways. International Journal of Academic Research in Economics and Management Sciences, 5(4), 201- 226.

Aldaihani, F. M. F., \& Azman N. (2019). Impact of Relationship Marketing on Customers Loyalty of Islamic Banks in The State of Kuwait. International Journal of Scientific $\mathcal{E}$ Technology Research, 8(11), 788-808.

Baines, P. \& Fill, C. (2014). Marketing. 3rd edn. Oxford: Oxford University Press

Baird, C. H., \& Parasnis, G. (2011), From Social Media To Social Customer Relationship Management. Strategy E Leadership, 39(5), 30-37.

Bajs, I. P. (2015). Tourist Perceived Value, Relationship to Satisfaction and Behavioral Intentions: The Example of The Croatian Tourist Destination Dubrovnik. Journal of Travel Research, 54, 122-134.

Balakrishnan, B. K., Dahnil, M. I., \& Yi, W. J. (2014). The Impact of Social Media Marketing Medium Toward Purchase Intention and Brand Loyalty Among Generation Y. Procedia-Social and Behavioral Sciences, 148, 177-185.

Basalamah, M. R., \& Moeljadi, Sunaryo, \& Sudjatno. (2018). The Effect of Service Quality and Relationship Marketing Towards Customer Loyalty for Sharia Banking (Sharia Banking Study in Makassar Indonesia). International Review of Management and Marketing, 8(1): 107-13.

Beatson, A., Lings, I., \& Gudergan. S. (2007). Employee Behaviour and Relationship Quality: Impact on Customers. The Service Industries Journal, 211-223.

Beech, J., Chadwick, S., \& Tapp, A. (2000). Surfing In the Premier League: Key Issues for Football Club Marketers Using the Internet. Managing Leisure, 5(2), 51-64. doi: I $0.1080 / 13606710050022511$.

Bejou, D., Wray, B., \& Ingram, T. N. (1996) Determinants of Relationship Quality: An Artificial Neural Network Analysis, Journal Business Research. 
Ben Naoui, F. \& Zaiem, I. (2010). The Impact of Relationship Quality on Client's Loyalty: An Application in The Parapharmaceutical Industry. The International Journal of Pharmaceutical and Healthcare Marketing, 4(2), 137156.

Bhagat, P. S., Klein, A., \& Sharma, V. (2009). The Impact of New Media on Internet-Based Group Consumer Behavior. Journal of Academy of Business and Economics, 9, 83-94.

Bilgihan, A., Okumus, F., \& Cobanoglu, C. (2013). Generation Y Travelers' Commitment to Online Social Network Websites. Tourism Management, 35, 13-22.

Bilgin, Y. (2018). The Effect of Social Media Marketing Activities on Brand Awareness, Brand Image and Brand Loyalty. Business \& Management Studies: An International Journal, 6(1), 128-148.

Bojei \& Alwie (2010). The Influence of Relationship Quality on Loyalty in Service Sector. International Journal of Economics and Management. 4(1), 81-100.

Bolton, R. N., Kannan, P. K. \& Bramlett, M. (2000). Implications for Loyalty Program Membership and Service Experiences for Customer Retention and Value. Journal of Academy of Marketing Science, 28, 95-108.

Bowen, J. T. \& Shoemaker, S. (2003). Loyalty: A Strategic Commitment. Cornell Hotel and Restaurant Administration Quarterly, Oct-Dec 2003, 44, 5/6, 31-46.

Brodie, R. J., Hollebeek, L. D., Juric, B., \& Llic, A. (2011). Consumer Engagement: Conceptual Domain, Fundamental Propositions, And Implications for Research. Journal of Service Research, https://doi.org/10.1177/1094670511411703.

Chathoth, P. K., Ungson, G. R., Harrington, R. J., \& Chan, E. S. (2016). Co-Creation and Higher Order Customer Engagement in Hospitality and Tourism Services: A Critical Review. International Journal of Contemporary Hospitality Management, 28(2), 222-245.

Chen, C. F., \& Myagmarsuren, O. (2013). Exploring The Moderating Effects of Value Offerings Between Market Orientation and Performance in Tourism Industry. International Journal of Tourism Research, 15(6): 595-610.

Constantinides, E., \& Fountain, S. (2008). Web 2.0: Conceptual foundations and marketing issues. Journal of Direct Daw and Digital Marketing Practice, 9(3), 231-244. doi: I 0.1057/palgrave.dddmp.4350098.

Constantinides, E., Romero, C.L. \& Gómez Boria, M.A. (2008), Social Media: A New Frontier for Retailers. European Retail Research, 22, 1-28.

Cottrell, R. J. (1995). Proactive Relationship Management: The Next Step to Long Term Customer Loyalty. Customer Satisfaction Result, 25, 19-41.

Crosby, L. A.; Evans, K. R. \& Cowles, D. (1990). Relationship Quality in Services Selling: An Interpersonal Influence Perspective, Journal of Marketing, 54(3), 68-81.

De Wulf, K., Odekerken, Schroder G. \& La Cobucci, D. (2001). Investment In Consumer Relation. Journal of Marketing, 65, 33-50.

DeWitt, T. \& Brady, M. K. (2003). Rethinking Service Recovery Strategies: The Effect of Rapport on Consumer Responses to Service Failure. Journal of Service Research, 6(2), 193-207. 
Dijkmans, C., Kerkhof, P., \& Beukeboom, C. J. (2015). A Stage to Engage: Social Media Use and Corporate Reputation. Tourism Management, 47, 58-67.

Drury, G. (2008). Social Media: Should Marketers Engage and How Can It Be Done Effectively? Journal of Direct Data and Digiwl Marketing Practice, 9(3), 274--277. doi: I0. I057/palgrave.dddmp.4350096.

Dubois, T., \& Westerhausen, U. (2011). Brand Loyalty Creation Within Online Brand Communities. Marketing Communications Management, Thesis of Copenhagen Business School, Department of Marketing, Characters, 234.

Fotis, J., Buhalis, D., \& Rossides, N. (2011). Social Media Impact on Holiday Travel Planning: The Case of The Russian and The FSU Markets. International Journal of Online Marketing, 1(4), 1-19.

Foux, G. (2006). Consumer-Generated Media: Get Your Customers Involved. Brand Strategy, 38-39.

Fuentes-Blasco, M., Saura, G., Berenguer-Contri, G., \& Moliner-Velazquez. (2010). Measuring The Antecedents Of E-Loyalty and The Effect of Switching Costs on Website. Service Industries Journal, 30(11), 1837-1852.

Gamboa, A.M. \& Goncalves, H.M. (2014) Customer Loyalty Through Social Networks: Lessons from Zara on Facebook. Business Horizons, 57(6).

Godey, B., Manthiou, A., Pederzoli, D., Rokka, J., Aiello, G., Donvito, R., \& Singh, R. (2016). Social Media Marketing Efforts of Luxury Brands: Influence on Brand Equity and Consumer Behavior. Journal of Business research, 69(12): 5833-5841.

Gretzel, U. (2018). Influencer Marketing in Travel and Tourism. In Sigala, M. \& Gretzel, U. (Eds.), Advances in Social Media for Travel, Tourism and Hospitality: New Perspectives, Practice and Cases, 147-156. New York: Routledge.

Gretzel, U. \& Dinhopl, A. (2014). Breaking Up Is Hard to Do: Why Do Travellers Unlike Travel-Related Organizations? In Xiang, Z. \& Tussyadiah, I. (Eds.), Information and Communication Technologies in Tourism 2014, 267-280. Berlin: Springer.

Gretzel, U., Fesenmaier, D. R., Lee, Y.-J., \& Tussyadiah, I. (2011). Narrating Travel Experiences: The Role of New Media. In Sharpley, R. \& Stone, P. (Eds.), Tourist Experiences: Contemporary Perspectives, 171-182. New York: Routledge.

Gummerus, J., Liljander, V., Weman, E., \& Pihlström, M. (2012). Customer Engagement in A Facebook Brand Community. Management Research Review, 35(9), 857-877.

Gummesson, E. (1994). Marketing Relationship Marketing Operational. International Journal of Service Industry Management, 5(5), 5-20.

Gummesson, E. (1998). Relationship Marketing as A Paradigm Shift: Some Conclusions from the 30R Approach. Management Decision, 35(4), 267-72.

Habibi, M. R., Laroche, M., \& Richard, M. O. (2014). The Roles of Brand Community and Community Engagement in Building Brand Trust on Social Media. Computers in Human Behavior, 37, 152-161.

Han, X., Kwortnik, R. J., \& Wang, C. (2008). Service Loyalty: An Integrative Model and Examination across Service Contexts. Journal of Service Research, 11(1), 22-42. 
Hayes, A. F., \& Rockwood, N.J. (2020). Conditional Process Analysis: Concepts, Computation, And Advances in Modeling the Contingencies of Mechanisms. American Behavioral Scientist, 64, 19-54.

Hayes, A. F. (2013). Introduction To Mediation, Moderation and Conditional Process Analysis: A Regression-Based Approach. New York: Guilford Press.

Hennig-Thurau, T., Gwinner, K. P., \& Gremler, D. D. (2002). Understanding Relationship Marketing Outcomes: An Integration of Relational Benefits and Relationship Quality. Journal of Service Research, 4(3), 230-247.

Hennig-Thurau, T., Malthouse. E.C., Friege, C. Gensler, S., Lobschat, L., Rangaswamy, A., \& Skiera. (2010). The Impact of New Media on Customer Relationships. Journal of Service Research, 13(3), 311-330. doi: I0. I I 77/1094670510375460.

Holley, J. N. (2011). Customer Relationship Management: Emerging Practice, Process and Discipline, Journal of Economic and Social Research,3(2),1-34.

Hu, H. S., Kanddampully, J., \& Juwaheer, T. D. (2009). Relationships And Impacts of Service Quality, Perceived Value, Customer Satisfaction, And Image: An Empirical Study. The Service Industries Journal, 29(2), 111-125.

Huang, C. H. (2012). The impact of relationship quality on customer loyalty. Journal of Contemporary Management, October 2012. 53-68.

Husnain, M., \& Akhtar, M. W. (2015). Relationship Marketing and Customer Loyalty: Evidence from Banking Sector in Pakistan. Global Journal of Management and Business Research: EMarketing,15(10).

Hutter K., Hautz J., Dennhardt S. \& Fuller J. (2018). The Impact of User Interactions in Social Media On Brand Awareness And Purchase Intention: The Case Of MINI On Facebook. Journal of Product \& Brand Management, 22(5/6), 342-351

Jiaqi, y., Teo, B. S. X., Tingting, L., \& Jiaxun, Z. (2021). Influence Of Social Media Marketing in Building Relationship Between Brand Loyalty of Tourism Products and Products Service Quality. 2021 International Conference on Tourism, Economy and Environmental Sustainability. E3S Web of Conferences 251. https://doi.org/10.1051/e3sconf/202125103006.

Jin, N. H., Choi, H. S., \& Goh, B. (2011). Examining The Relationship Among E-Servicequal, Relational Benefits, And Relationship Quality in Online Tourism Portals: The Moderating Role of Personality Traits. 16th Graduate Students Research Conference, Houston, Texas.

Kahn, W. A. (1990). Psychological conditions of personal engagement and disengagement at work. Academy of Management Journal, 33, 692-724

Kanapathipillai, K. (2020). The Impact of The Silent Enemy (Covid-19 Pandemic) On the Marketing Efforts Undertaken by The Automotive Industries in Malaysia. European Journal of Management and Marketing Studies, 5(4), 1-21.

Kanapathipillai, K. (2021). The Influence of Social Media Technology with Reference to Facebook on Work Performance: Organisational Framework as Mediator. European Journal of Social Science Studies, 6(5), 74-108. 
Kaplan, A. M. \& Haenlein, M. (2016). Users of the World, Unite! The Challenges and Opportunities of Social Media, Business Horizons, 53 (1), 59-68.

Kaplan, A. M., \& Haenlein, M. (2010). Users Of the World, Unite! The Challenges and Opportunities of Social Media. Business Horizons, 53, 59-68.

Keating, B. W., Alpert, F., Kriz, A., \& Quazi, A. (2010). Exploring The Mediating Role of Relationship Quality in Online Services. MPRA Paper No. 40506. Retrieved from: https://mpra.ub.uni-muenchen.de/40506.

Keaveney, S. M. (1995). Customer Switching Behaviour in Service Industries : An Exploratory Study. Journal of Marketing 59, 71 - 82.

Keshavarz, Y., \& Ali M. H. (2015). The Investigation of The Hotels Service Quality Effects on Tourist Loyalty. International Journal of AYER, 2, 327-342.

Keshavarz, Y., Jamshidi, D., \& Bakhtazma, F. (2016). The Influence of Service Quality on Restaurants' Customer Loyalty. Arabian Journal of Business and Management Review, 6(4), 1-16.

Khoa, B. T. (2019). The Antecedents of Relationship Marketing and Customer Loyalty: A Case of the Designed Fashion Product. Journal of Asian Finance, Economics and Business, 7(2),195-204.

Kietzmann, J. H., Hermkens, K., McCarthy, I. P., \& Silvestre, B. S. (2011). Social Media? Get Serious! Understanding The Functional Building Blocks of Social Media. Business Horizons, 54, 241-251.

Kim, J, Jin, B, \& Swinney, J. (2009). The role of e-tail quality, e-satisfaction and e-trust in online loyalty development process. Journal Of Retailing \& Consumer Services, 16(4), 239-247.

Kim, W., \& Han, H. (2008). Determinants of Restaurant Customers' Loyalty Intentions: A Mediating Effect of Relationship Quality. Journal of Quality Assurance in Hospitality $\mathcal{E}$ Tourism, 9(3), 219-239.

Kotler, P., Kartajaya, H., \& Setiawan, I. (2010). Marketing 3.0: From Products to Customers to The Human Spirit. Hoboken, NJ: Wiley.

Krejcie, R. V., \& Morgan, D. W. (1970). Determining Sample Size for Research Activities. Educational \& Psychological Measurement.

Ladkin, A., \& Buhalis, D. (2016). Online And Social Media Recruitment: Hospitality Employer and Prospective Employee Considerations. International Journal of Contemporary Hospitality Management, 28(2), 327-345.

Laroche, M., Habibi, M. R., Richard, M. O., \& Sankaranarayanan, R. (2012). The Effects of Social Media Based Brand Communities On Brand Community Markers, Value Creation Practices, Brand Trust And Brand Loyalty. Computers in Human Behavior, 28, 1755-1767.

Leidner, D. E. \& Kayworth, T. (2016). A Review of Culture in Information Systems Research: Toward a Theory of Information Technology Culture Conflict, MIS Quarterly, 30(2), 357-399.

Leung, D., Law, R., van Hoof, H. \& Buhalis, D. (2013). Social Media in Tourism and Hospitality: A Literature Review. Journal of Travel \& Tourism Marketing, 30(3), 3-22. 
Liang C. J., \& Wang, W. H. (2006). The Behavioural Sequence of The Financial Services Industry in Taiwan: Service Quality, Relationship Quality and Behavioural Loyalty. The Service Industries Journal, 26(2), 119-145.

Lin, C. P., \& Ding, C. G. (2006). Evaluating Group Differences in Gender During the Formation of Relationship Quality and Loyalty in ISP Services. Journal of Organisational and End User Computing, 18(2), 38-62.

Lin, C. P. and Ding, C. G. (2009). Comparing The Main Effects and Moderating Effects of Education Among Three Models in IT Service: A Quantitative Approach. Quality and Quantity, 43, 617-633.

Ma, C., Jang, G., \& Lai, M. (2020). The Influence of Transaction Cost and Service Quality on Partner Loyalty - The Mediating Effect of Relationship Quality. MATEC Web of Conferences 325.

Madera, J. M. (2012). Using Social Networking Websites as A Selection Tool: The Role of Selection Process Fairness and Job Pursuit Intentions. International Journal of Hospitality Management, 31(4), 1276-1282.

Mangold, G., \& Faulds, D. (2009). Social Media: The New Hybrid Element of the Promotion Mix. Business Horizons, 52, 357-365.

Marina, S., Kartini, D., Sari, D., \& Padmasasmita, S. (2016). Customer Loyalty as The Implications of Price Fairness Determined by Relationship Marketing and Service Quality of Airline Services. South East Asia Journal of Contemporary Business, Economics and Law, 11(2), $43-51$.

Menteiro, P. R. R., \& Afonso, V. (2010). Relationship Marketing in Supply Chain: An Empirical Analysis in The Brazilian Service Sector. IV Encontro de Marketing da ACVAD : $1-15$.

Mershon, P. (2012). 5 Social Media Marketing Trends: New Research. Social Media Examiner. Retrieved from http://www.socialmediaexaminer.com/5-social-media-marketingtrends-new-research-2/

Miller, R., \& Lammas, N. (2010). Social Media and Its Implications for Viral Marketing. Asia Pacific Public Relations Journal, 11(1), 1-9.

Mimouni, A. \& Volle, P. (2003). Benefices per us de la fidelisation et qualit. relationnelle: Une application exploratoire au secteur $d u$ transport aerien. Proceedings in the AFM Congress, 2003, Tunisia. 532-549.

Ministry of Tourism, Arts and Culture Malaysia, MOTAC. (2021). Industry Development. Retrieved from: http://motac.gov.my.

Ministry of Tourism, Arts and Culture Malaysia, MOTAC. (2021). National Tourism Policy 2020-2030. Retrieved from: http://motac.gov.my.

Mohamed, B. (2001). Isu-Isu Terpilih Perancangan Pelancongan, Tokyo, Ewa Inc.

Mola, F., \& Jusoh, J. (2011). Service Quality in Penang Hotels: A Gap Score Analysis. World Applied Sciences Journal, 12: 19-24.

Moliner, M. A., Sanchez, J., Rodriguez, R. M., and Cllarisa, L. (2007). Relationship Quality with A Travel Agency: The Influence of The Post-Purchase Perceived Value of A Tourism Package. Tourism and Hospitality Research, 7(3/4): 194-221. 
Morgan, R. M., \& Hunt, S. D. (1994). The Commitment-Trust Theory of Relationship Marketing. Journal of Marketing, 58, 20-38

Munar, A. M., Gyimóthy, S., \& Cai, L. (Eds.). (2013). Tourism social media: Transformations in identity, community and culture. Bingley, UK: Emerald Group Publishing.

Nakhleh, H. M. A. (2012). The Relationship Between Customer Relationship Marketing Tactics, Relationship Quality and Customer's Loyalty in Mobile Communication Industry. Academic Research International, 3(2), 538-47.

Nauroozi, S. E., \& Moghadam, S. K. (2015). The Study of Relationship Marketing with Customer Satisfaction and Loyalty. International Journal of Innovation and Research in Educational Sciences, 2(2), 2349-5219.

Ndubisi, N. O, Chan, K. W., \& Gibson, C. (2007). Supplier-customer relationship management and customer loyalty: The banking industry perspective. Journal of Enterprise Information Management, 25(1), 98-106

Ndubisi, N. O. (2007). Relationship Marketing and Customer Loyalty. Marketing Intelligence and Planning, 25(1), 98-106.

Ndubisi, N. O. and Chan, K., W. (2005). Factorial And Discriminates Analysis of The Underpinning of Relationship Marketing and Customer Satisfaction. International Journal of Bank Marketing, 23(3), 542-557

Njuguna, R. K., \& Mirugi, S. (2017). The Effectiveness of Relationship Management and Service Quality on Service Delivery. International Journal of Sales, Retailing and Marketing, 6(2), 52-59

Ogungbade, D. R. (2015). Exploring the Relationship between Relationship Marketing, Relationship Quality and Customer Loyalty in Nigerian Telecommunication Industry. Global Journal of Emerging Trends in e-Business and Consumer Psychology, 1(2), 269-281.

Oliver, R. L. (1999). Whence Consumer Loyalty. Journal of Marketing, 63, 33-44.

Palmatier, R. W., Dant, R. P., Grewal, D., \& Evans, K. R. (2006). Factors Influencing the Effectiveness of Relationship Marketing: A Meta-Analysis. Journal of Marketing, 70(4), 136-153.

Parasuraman, A., Zeithaml A. V., \& Berry L. L. (1985). A conceptual model of service quality and its implications for future research, Journal of Marketing, 49, 41-50

Pongpaew, W., Speece, M., \& Tiangsoongnern, L. (2016). Customer Brand Engagement, Perceived Social Presence, and Brand Trust and Loyalty in Corporate Facebook. In 2016 Annual Conference of the Emerging Markets Conference Board, Chulalongkorn University, Bangkok, Thailand, 6-8.

Prime Minister's Office of Malaysia Official Website. (2021). National Tourism Policy 2020 -2030. Retrieved from: https://www.pmo.gov.my.

Rashtchy, F., Kessler, A. M., Bieber, P. J., Shindler, N. H., \& Tzeng, J. C. (2007). The User Revolution: The New Advertising Ecosystem and The Rise of The Internet as A Mass Medium, Minneapolis, Piper Jaffray Investment Research.

Rauyruen, P., \& Miller, K. E. (2007). Relationship Quality as A Predictor of B2B Customer Loyalty. Journal of Business Research, 60(1): 21-31. 
Reichheld, F. F., Markey, R. G. \& Hopton, C. (2000). E-Customer Loyalty-Applying the Traditional Rules of Business for Online Success. European Business Journal, 12(4), 173-180.

Rezaei, A., \& Khajei, R. (2011). The Impact of Relationship Marketing Tactics on Customer Loyalty: The Mediation Role of Relationship Quality. International Journal of Business Administration, 2(3), 83-93.

Ruswanti, E., \& Lestari, W.P. (2016). The Effect of Relationship Marketing Towards Customer's Loyalty Mediated by Relationship Quality (Case Study in Priority Bank in Niaga). DeReMa Jurnal Manajemen, 11(2), 191 -211.

Sakolnakorn, T. P. N. (2020). Important Factors and Policies That Contributed to Tourism in Malaysia Between 1991 and 2018. International Journal of Innovation, Creativity and Change, 14(12), $969-80$.

Salanova, M., Agut, S., \& Peiro, J. M. (2005). Linking Organizational Resources and Work Engagement to Employee Performance and Customer Loyalty: The Mediation of Service Climate. Journal of Applied Psychology, 90, 1217- 1227.

Samudro, A., Sumarwan, U., Simanjuntak, M., \& Yusuf, E.Z. (2019). Building The Model of a Relationship's Quality: An Investigation of The Chemical Industry. Jurnal Ilmiah Manajemen, 9(3), 528-43.

Sanchez, J., Moliner, M. A., Callarisa, L., \& Rodriguex, R. M. (2007). Relationship Quality of An Establishment and Perceived Value of a Purchase. The Service Industries Journal, 27(2), 151-174.

Shahrokh, Z. D., Oveisi, N., \& Timasi, S. M. (2013). The Effects of Customer Loyalty on Repurchase Intention in B2c E-Commerce, A Customer Loyalty Perspective. Journal of Basic and Applied Scientific Research, 3(6), 636-644.

Shaimaa, S. B., \& Doma, A. (2013). Relationship Quality as Predictor of B2B Customer Loyalty. Systemics Cybernetics and Informatics, 11(1), 72-78.

Shalbaya, Ahmed Fawzi (2012). E-Commerce and the Factors Affecting E-loyalty in the EBusiness Market, An Empirical Study on the E-Business Market in the Hashemite Kingdom of Jordan. Master Thesis, Middle East University.

Sheth, J. N., \& Parvatiyar, A. (2000). Handbook of relationship marketing. London: Sage Publications, Inc.

SI, S. (2016). Social Media and Its Role in Marketing. Business And Economics Journal, 7(1). https://doi.org/10.4172/2151-6219.1000203

Sirdeshmukh, D., Singh, J., \& Sabol, B. (2002). Consumer trust, value, and loyalty in relational exchanges. Journal of Marketing,66(1): 15-37.

Smith, J. B. (1998). Buyer-Seller Relationships: Similarity, Relationship Management, and Quality. Psychology and Marketing, 15(1), 3-21.

Stringer, K. (2006). Advertising: If They Make It, They Will Watch - Companies Let Ordinary People Create Commercials. Detroit Free Press. Retrieved from: http://www.freep.com/apps. 
Suseno, Y., Laurell, C. \& Sick, N., 2018. Assessing Value Creation in Digital Innovation Ecosystems: A Social Media Analytics Approach. The Journal of Strategic Information Systems, 27(4), 335-349.

Too, L. H., Souchon, A. L., \& Thirkell, P. C. (2001). Relationship Marketing and Customer Loyalty in A Retail Setting: A Dyadic Exploration. Journal of Marketing Management, 17(3-4), 287-320.

Tseng, Y. M. (2007). The Impacts of Relationship Marketing Tactics on Relationship Quality in Service Industry. Business Review Cambridge, 7(2), 310-314.

Turri, A. M., Smith, K. H., \& Kemp, E. (2013). Developing affective brand commitment through social media. Journal of Electronic Commerce Research, 14(3), 201.

Verhoef, P. C. (2003). Understanding the Effect of Customer Relationship Management Efforts on Customer Retention and Customer Share Development. Journal of Marketing, 67, 30-45.

Vesel, P. \& Zabkar, V. (2010). Comprehension of Relationship Quality in Retail Environment. Managing Service Quality, 20(3), 213-235.

Vivek, S. D., Beatty, S. E., \& Morgan, R. M. (2012). Customer Engagement: Exploring Customer Relationships Beyond Purchase. Journal of Marketing Theory and Practice, 20(2), 122-146.

Vollmer, C., \& Precourt, G. (2008). Always on: Advertising, Marketing and Media in an era of consumer control. McGraw Hill, New York.

Werthner, H., \& Klein, S. (1999). Information Technology and Tourism: A Challenging Relationship. Springer-Verlag Wien.

White, N. R., \& White, P. B. (2007). Home And Away: Tourists in A Connected World. Annals of Tourism Research, 34(1), 88-104.

Wong, A. \& Sohal, A. (2006). Understanding The Quality of Relationship in Consumer Services: A Study in A Retail Environment. The International Journal of Quality and Reliability Management, 23(3). 244-264.

Xiang, Z., \& Gretzel, U. (2010). Role of social media in online travel information search. Tourism management, 31(2), 179-188.

Zhang, Y., Yang, Y., Wei, K. K., Ramsey, E., McCole, P., \& Chen H. (2011). Repurchase Intention in B2C E-Commerce. A Relationship Quality Perspective. Information And Management, 48(6), 192-200. 

applied to their work. Under the terms of this license, no permission is required from the author(s) or publisher for members of the community to copy, distribute, transmit or adapt the article content, providing a proper, prominent and unambiguous attribution to the authors in a manner that makes clear that the materials are being reused under permission of a Creative Commons License. Views, opinions and conclusions expressed in this research article are views, opinions and conclusions of the author(s). Open Access Publishing Group and European Journal of Management and Marketing Studies shall not be responsible or answerable for any loss, damage or liability caused in relation to/arising out of conflict of interests, copyright violations and inappropriate or inaccurate use of any kind content related or integrated on the research work. All the published works are meeting the Open Access Publishing requirements and can be freely accessed, shared, modified, distributed and used in educational, commercial and non-commercial purposes under a Creative Commons Attribution 4.0 International License (CC BY 4.0). 